\title{
ERRATUM
}

\section{Challenge with Hepatitis B Vaccine in Children Previously Vaccinated with a Hepatitis B-Containing Combination Vaccine}

Philippe Reinert · Sandro Cinquetti · Benoit Soubeyrand · Luigi R. Biasio · Gilles Meghlaoui · Stéphane Thomas · Michael Watson

(C) 2010 Springer Healthcare

Erratum to: Reinert $P$, et al. Challenge with hepatitis $B$ vaccine in children previously vaccinated with a hepatitis B-containing combination vaccine. Adv Ther. 2010;27(1):28-38.

The publishers would like to apologize for an error that occurred in the publication of abovementioned article, by Philippe Reinert and colleagues, in which the incorrect copyright statement was printed.

This article was published with Springer's Open Choice program and, as such, the copyright line should have read: “( 2010 The Author(s). This article is published with open access at Springerlink.com."

In accordance with Springer's Open Choice guidelines, the article should also have contained the following statement at the end of the article, reading: "Open Access. This article is distributed under the terms of the Creative Commons Attribution Noncommercial License which permits any noncommercial use, distribution, and reproduction in any medium, provided the original author(s) and source are credited." 